\title{
Must TREATY Violations Be REMEDIED?: A CRITIQUE OF SANCHEZ-LLAMAS V. OREGON
}

John Quigley*

TABLE OF CONTENTS

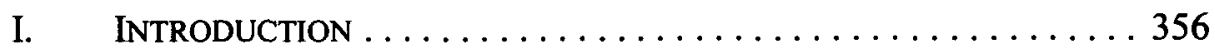

II. BACKGROUND to SANCHEZ-LLAMAS V. OREGON $\ldots \ldots \ldots \ldots 357$

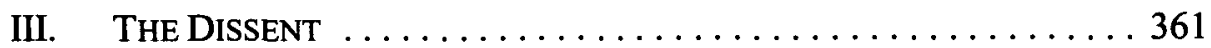

IV. INTERNATIONAL LAW ON REMEDY FOR A TREATY

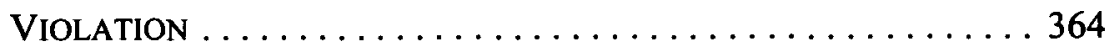

V. The Law of State ResponsibiLity $\ldots \ldots \ldots \ldots \ldots \ldots \ldots$

VI. STATE RESPONSIBILITY FOR VIOLATION OF CONSULAR

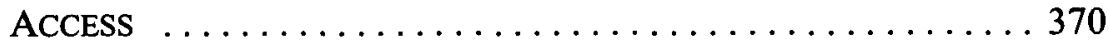

VII. VIEWS of STATES PARTY TO THE VCCR $\ldots \ldots \ldots \ldots \ldots \ldots 372$

VIII. VIEW of THE DePARTMENT OF STATE $\ldots \ldots \ldots \ldots \ldots \ldots \ldots 378$

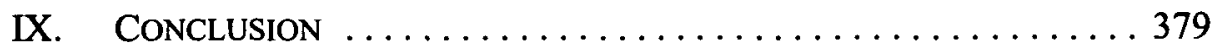

* President's Club Professor of Law, The Ohio State University. LL.B., M.A., Harvard University. The author served as co-counsel in an amicus curiae brief in the Supreme Court of the United States in support of Sanchez-Llamas. 


\section{INTRODUCTION}

In Sanchez-Llamas v. Oregon, ${ }^{\text {a }} 2006$ case involving a treaty, the Supreme Court of the United States made the following statement: "where a treaty does not provide a particular remedy, either expressly or implicitly, it is not for the federal courts to impose one on the States through lawmaking of their own."2 The proposition asserted in this sentence - that a particular remedy is required for a treaty violation only if specified in the treaty itself -involves a departure from two hundred years of Supreme Court case law on remedies for a treaty violation. Treaties are to be enforced by the courts under the Constitution's Supremacy Clause. ${ }^{3}$ The approach the Court takes towards treaties in SanchezLlamas would mean a virtual gutting of the treaty provision of the Supremacy Clause.

The Court gave little indication of the reasoning that led it to such a narrow view of required remedies for a treaty breach. It cited no precedents and no sources in treaty law or in general international law. Four justices, dissenting, challenged the Court on the point. ${ }^{4}$ They referred to prior cases of treaty breach in which the Court gave a remedy, even though none was specified in the particular treaty. ${ }^{5}$ The dissenters thus viewed the Court's approach as inconsistent with its own case law. ${ }^{6}$ The dissenters did not, however, analyze the issue of remedy for a treaty breach, and hence did not explain why they thought the Court to be wrong.

The Court, in fact, is quite wrong in saying that only a remedy specifically expressed in a treaty need be given. Remedies are required in case of treaty breach, but rarely are they specified in the treaty itself. A separate branch of international law, which serves as an adjunct to treaty law, provides for remedies. ${ }^{7}$ It was by ignoring this branch of international law that the Court fell into error. This Article examines both the Supreme Court's precedents on remedies for treaty breach and the relevant international law. It suggests an

1 Sanchez-Llamas v. Oregon, 126 S. Ct. 2669 (2006).

${ }^{2}$ Id. at 2680.

${ }^{3}$ U.S. CONST. art. VI, $\S 2$.

${ }^{4}$ Id. at 2694-98. Breyer, Stevens and Souter ascribed to the entire dissent. Id. at 2690. Ginsburg joined Part II of the dissent, which is the portion of the dissent to which this Article relates. Id.

${ }^{5} I d$. at 2696.

${ }^{6}$ Id. at 2696.

${ }^{7}$ See discussion infra Part V. 
approach consistent with the Court's prior cases, and with international law, that should be followed in cases of treaty breach.

\section{BACKGROUND TO SANCHEZ-LLAMAS V. OREGON}

The treaty provision at issue in Sanchez-Llamas v. Oregon was Article 36 of the Vienna Convention on Consular Relations (VCCR) ${ }^{8}$ That provision imposes obligations on a state (in the sense of nation state) whose authorities arrest a foreign national. ${ }^{9}$ One of the most widely ratified treaties, with 171 states as parties, the VCCR was ratified by the United States in $1969 .{ }^{10}$ For domestic law purposes, this ratification calls into play the Supremacy Clause of the United States Constitution, which requires the courts to regard treaties as law. ${ }^{11}$ As construed and implemented by the United States Supreme Court, the Supremacy Clause means that if a treaty provides a right to a given category of persons, the courts will enforce that right for anyone falling into that category. ${ }^{12}$

The idea underlying VCCR Article 36 is that a nation state, as represented by its consuls, may communicate with any of its nationals who happen to be in the other state, including those under arrest. ${ }^{13}$ Article 36 provides a right for a consul to communicate with an arrested national, and a reciprocal right for the arrested national to communicate with the consul. ${ }^{14}$ Further, and importantly, Article 36 gives the national a right to be informed of the right of access to the consul. ${ }^{15}$ If the foreign national opts for consular access, the

8 Vienna Convention on Consular Relations art. 36, done Apr. 24, 1963, 21 U.S.T. 77, 596 U.N.T.S. 261 [hereinafter VCCR].

${ }^{9}$ Id.

${ }^{10}$ See Multilateral Treaties Deposited with the Secretary-General: Vienna Convention on Consular Relations, available at http://untreaty.un.org/english/bible/englishinternetbible/part// chapterIII/treaty31 asp (last visited Jan. 26, 2008).

${ }^{11}$ U.S. CONST. art. VI, $\S 2$ ("This Constitution, and the Laws of the United States which shall be made in Pursuance thereof; and all Treaties made, or which shall be made, under the Authority of the United States, shall be the Supreme Law of the Land; and the Judges in every State shall be bound thereby, any Thing in the Constitution or Laws of any State to the Contrary notwithstanding.").

12 Ware v. Hylton, 3 U.S. (3 Dall) 199 (1796); Foster v. Neilson, 27 U.S. (2 Pet.) 253 (1829).

13 LUKe T. Lee, Consular LaW and Practice 133 (2d ed. 1991).

${ }^{14}$ VCCR, supra note 8, art. 36(1)(a).

${ }^{15}$ Id. art. 36(1)(b). 
authorities must, at the national's option, themselves contact the consul, or allow the national to do so. ${ }^{16}$

A consul, once notified, may assist the foreign national in a variety of ways; for example, by ensuring that the national is being treated properly by the arresting authorities ${ }^{17}$ or by explaining the rights of an arrested person in a fashion, and perhaps in a language, that will be better understood than the explanation that may be given by police or by a local attorney. ${ }^{18}$ A consul may advise the national on the local system for criminal representation. ${ }^{19}$ A consul

${ }^{16}$ Id. art. 36:

1. With a view to facilitating the exercise of consular functions relating to nationals of the sending State:

(a) consular officers shall be free to communicate with nationals of the sending State and to have access to them. Nationals of the sending States shall have the same freedom with respect to communication with and access to consular officers of the sending State;

(b) if he so requests, the competent authorities of the receiving State shall, without delay, inform the consular post of the sending State if, within its consular district, a national of that State is arrested or committed to prison or to custody pending trial or is detained in any other manner. Any communication addressed to the consular post by the person arrested, in prison, custody or detention shall also be forwarded by the said authorities without delay. The said authorities shall inform the person concerned without delay of his rights under this sub-paragraph;

(c) consular officers shall have the right to visit a national of the sending State who is in prison, custody or detention, to converse and correspond with him and to arrange for his legal representation. They shall also have the right to visit any national of the sending State who is in prison, custody or detention in their district in pursuance of a judgment. Nevertheless, consular officers shall refrain from taking action on behalf of a national who is in prison, custody or detention if he expressly opposes such action.

2. The rights referred to in paragraph 1 of this Article shall be exercised in conformity with the laws and regulations of the receiving State, subject to the proviso, however, that the said laws and regulations must enable full effect to be given to the purposes for which the rights accorded under this Article are intended.

177 DEP'T OF STATE FOREIGN AFFAIRS MANUAL $\S 423.10$ (2004) (suggesting that a consul take photographs of recently arrested U.S. nationals in case the person is subsequently physically abused), available at http://www.state.gov/documents/organization/86605.pdf.

${ }^{18}$ Id. $\S 415.3$.

${ }^{19}$ Id. 
may suggest names of attorneys who, in the past, have represented persons of the particular nationality. ${ }^{20} \mathrm{~A}$ consul who considers that the national's rights are being violated may file a protest with the local authorities. ${ }^{21}$

Sanchez-Llamas, a Mexican, was arrested in Oregon and informed of his Miranda rights, but was not informed of his right to contact a consul of Mexico. ${ }^{22}$ This failure was in violation of Article 36, a violation that is not disputed. $^{23}$ Police proceeded to interrogate Sanchez-Llamas shortly after arresting him and elicited a statement from him containing incriminating elements. ${ }^{24}$ Sanchez-Llamas was charged with attempted murder. ${ }^{25}$ Prior to trial, he filed a motion to suppress the statement, on grounds of the authorities' failure to comply with Article $36 .{ }^{26}$ The motion was denied. Sanchez-Llamas was convicted at trial and sentenced to "twenty and one-half" years in prison. ${ }^{27}$ On appeal, the Oregon Supreme Court affirmed. ${ }^{28}$ Sanchez-Llamas sought review by way of certiorari in the Supreme Court of the United States, which accepted the case for review. ${ }^{29}$

The Supreme Court of the United States left the conviction in place. ${ }^{30}$ In its decision, the Court avoided a broader question that had been contested below as to whether Article 36 provides a right that a court must implement for a foreign national. ${ }^{31}$ Instead, the Court focused on the remedy sought by Sanchez-Llamas, suppression, posing for itself the question of whether suppression is required when a statement is elicited from a foreign national who was not informed of the right to contact a consul. ${ }^{32}$ As recounted by the Court:

Sanchez-Llamas argues that the trial court was required to suppress his statements to police because authorities never told

${ }^{20}$ Id. $\S \S 415.4,423.4$.

${ }^{21}$ Id. $\S 426.1$.

22 Sanchez-Llamas v. Oregon, 126 S. Ct. 2669, 2676 (2006).

${ }^{23} \mathrm{Id}$.

${ }^{24}$ Id.

${ }^{25}$ Id.

${ }^{26} \mathrm{Id}$.

${ }^{27}$ Id.

${ }^{28}$ State v. Sanchez-Llamas, 108 P.3d 573 (Or. 2005).

${ }^{29}$ Sanchez-Llamas v. Oregon, 546 U.S. 1001 (2005).

$30126 \mathrm{~S}$. Ct. at 2688 (affirming decision of Supreme Court of Oregon).

${ }^{31}$ Id. at $2677-78$ (indicating that the Court will assume, without deciding, that VCCR Art. 36 granted enforceable rights to Sanchez-Llamas).

${ }^{32} I d$. at 2678. 
him of his rights under Article 36. He refrains, however, from arguing that the Vienna Convention itself mandates suppression. We think this a wise concession. The Convention does not prescribe specific remedies for violations of Article 36. Rather, it expressly leaves the implementation of Article 36 to domestic law: Rights under Article 36 are to "be exercised in conformity with the laws and regulations of the receiving State." As far as the text of the Convention is concerned, the question of the availability of the exclusionary rule for Article 36 violations is a matter of domestic law. ${ }^{33}$

The Court went on to ask itself whether suppression was required as a matter of domestic law and decided that it was not. ${ }^{34}$ Then it reverted to the question of whether a remedy was required on the basis of the VCCR or any emanation from it. ${ }^{35}$ The Court said:

[O]ur authority to create a judicial remedy applicable in state court ${ }^{36}$ must lie, if anywhere, in the treaty itself. ... If we were to require suppression for article 36 violations without some authority in the Convention, we would in effect be supplementing those terms by enlarging the obligations of the United States under the Convention. This is entirely inconsistent with the judicial function. Cf. The Amiable Isabella, 6 Wheat. 1, 71 (1821) (Story, J.) ("[T]o alter, amend, or add to any treaty, by inserting any clause, whether small or great, important or trivial, would be on our part an usurpation of power, and not an exercise of judicial functions. It would be to make, and not to construe a treaty"). ${ }^{37}$

${ }^{33}$ Id. (citation omitted).

${ }^{34}$ Id. at 2679.

${ }^{35}$ Id.

${ }^{36}$ The Court did not speculate whether a different analysis would apply if Sanchez-Llamas had been prosecuted federally.

37126 S. Ct. at 2679. 
The Court said that a self-executing treaty binds states, like Oregon, under the Supremacy Clause, and that:

[W] here a treaty provides for a particular judicial remedy, there is no issue of intruding on the constitutional prerogatives of the States or the other federal branches. Courts must apply the remedy as a requirement of federal law. . . . But where a treaty does not provide a particular remedy, either expressly or implicitly, it is not for the federal courts to impose one on the States through lawmaking of their own. ${ }^{38}$

\section{THE DISSENT}

The Court's four dissenters disputed the proposition that a court cannot impose a remedy when the treaty is silent on the issue. ${ }^{39}$ They responded to the majority by saying that the Court has often provided a remedy for a treaty violation, even absent specification of a remedy in the treaty itself: "[T]his Court has routinely permitted individuals to enforce treaty provisions similar to Article 36 in domestic judicial proceedings." ${ }^{, 40}$

The dissenters cited three cases in which the Court had provided a remedy for violation of a treaty where the treaty itself contained no language about a remedy. ${ }^{41}$ United States $v$. Rauscher ${ }^{42}$ involved an extradition treaty, which, as construed by the Court, allowed the requesting state to prosecute only for the offense on which it requested extradition. ${ }^{43}$ Rauscher was extradited to the United States on one offense, but then the prosecution characterized the crime differently and made it the subject of a different offense. ${ }^{44}$ The extradition treaty said nothing about any right for the extraditee in that situation, limiting itself rather to the obligation of the requesting state not to charge any different offense. $^{45}$ Since the treaty did not mention any right for the extraditee, it

${ }^{38} I d$. at 2680 .

${ }^{39} I d$. at 2693-98 (Breyer, J., dissenting).

40 Id. at 2696.

41 Id.

42119 U.S. 407 (1886).

${ }^{43}$ Id. at 419.

${ }^{44}$ Id. at 409 (stating that Rauscher was extradited on the charge of murder, but was charged with the lesser offense of inflicting cruel and unusual punishment on another crew member of his vessel on the high seas).

${ }^{45}$ Id. at $410-11$. 
mentioned no remedy for the extraditee. ${ }^{46}$ Nonetheless, when Rauscher challenged the additional charge, the Court gave him a remedy by ruling that the additional charge could not be laid. ${ }^{47}$

Kolovrat v. Oregon ${ }^{48}$ involved a provision in a U.S.-Serbia treaty that entitled Serb nationals to inherit personal property on par with U.S. nationals. ${ }^{49}$ Oregon, by statute, permitted foreigners to inherit only if it appeared that a U.S. national would, in like circumstances, be entitled to inherit under the law of the other country. ${ }^{50}$ On the basis of that statute the Oregon Supreme Court refused to let the foreigners inherit. ${ }^{51}$ In the view of the Supreme Court of the United States, the Oregon statute, as applied to these foreigners, was inconsistent with the treaty. ${ }^{52}$ Even though the treaty said nothing about remedy, the Court reversed the Oregon Supreme Court and ordered that the property in question go to the foreigners. ${ }^{53}$

Asakura $v$. Seattle involved a Seattle ordinance forbidding foreigners to be pawnbrokers. $^{54}$ Asakura, a Japanese national who was engaged in pawnbroking in Seattle when the ordinance was adopted, sued Seattle to restrain it from enforcing the ordinance against him. ${ }^{55}$ A treaty with Japan gave Japanese citizens a right to carry on trade in the United States on par with U.S. nationals. ${ }^{56}$ The Court ruled that the treaty right prevailed over the ordinance, so that the ordinance could not be enforced against a Japanese national. ${ }^{57}$ The treaty contained no provision about remedy. ${ }^{58}$ Nonetheless, the Court provided Asakura a remedy by ruling that the ordinance could not be enforced against him. ${ }^{59}$

In all three of these cases, a treaty provided a right but was silent as to a remedy. In each case the Court provided a remedy. In none of the three did the Court feel the need to engage in any analysis, like that in which the Court

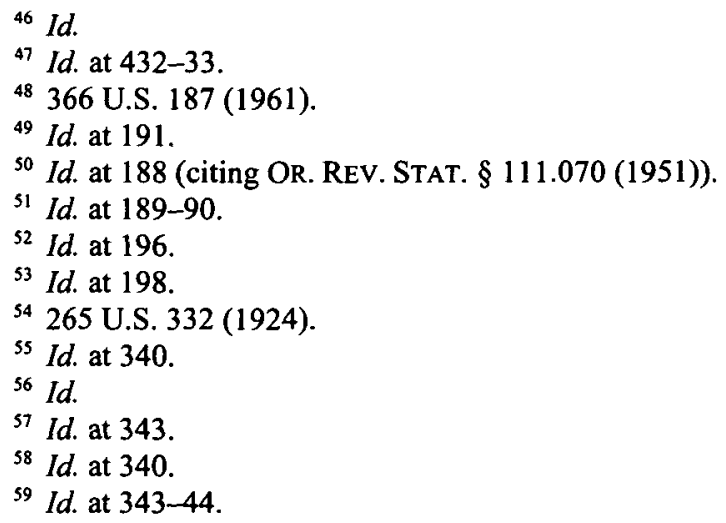


engaged in Sanchez-Llamas, as to whether the remedy was to be found in domestic law or in international law. In each of the three cases, the Court appeared to view it as axiomatic that if a treaty provided a right, the Court must provide a remedy. ${ }^{60}$

In Sanchez-Llamas, the Court did not refer to any of these three cases, or to any prior cases on remedy for a treaty violation. It is thus not clear whether the Court meant to depart from these prior cases or whether it simply overlooked them.

The dissenters, curiously, did not challenge the Court on its citation to The Amiable Isabella ${ }^{61}$ The Court did not, in its quotation from that case, indicate what was at issue there. ${ }^{62}$ Had the Court done so, the quotation's irrelevance would have been obvious. The Amiable Isabella does not stand for the proposition that a court may not devise an appropriate remedy for a treaty violation. The issue in The Amiable Isabella was whether the Court could add terms to a treaty that imposed obligations on the parties when the treaty itself failed to indicate those terms. ${ }^{63}$

The United States and Spain, as parties to a bilateral treaty, had specified that a document was to be appended to the treaty as an annex, but, for unknown reasons, they signed the treaty without including any annex. ${ }^{64}$ The question was whether the Court could, in effect, compose the annex or assume what its contents were to have been. ${ }^{65}$ The Court said it could not, and it was in that context that the Court made the statement quoted in Sanchez-Llamas that a court is not free to insert a clause. ${ }^{66}$ The clause about which the Court was speaking in The Amiable Isabella would have imposed on the parties obligations in addition to those found in the treaty. ${ }^{67}$ These additional obligations led the Court in The Amiable Isabella to say that it was not open to it as a court to insert a clause. ${ }^{68}$

${ }^{60} I d$. at 343; United States v. Rauscher, 119 U.S. 407, 432 (1886); Kolovrat v. Oregon, 366 U.S. 187,196 (1961).

${ }^{61} 19$ U.S. (6 Wheat.) 1 (1821).

${ }^{62}$ Sanchez-Llamas v. Oregon, 126 S. Ct. 2669, 2679 (2006) (quoting In re The Amiable Isabella, 19 U.S. (6 Wheat.) 1,71 (1821)).

${ }^{63} 19$ U.S. (6 Wheat.) at 71.

${ }^{64} I d$. at 70.

${ }^{65} \mathrm{Id}$. at $70-71$.

${ }^{66}$ Sanchez-Llamas, 126. S. Ct. at 2679.

${ }^{67} 19$ U.S. (6 Wheat.) at 71.

${ }^{68} I d$. 
The dissenters have the more correct view on remedy for a treaty violation, a view consistent with Supreme Court precedent. Their view is also correct as a matter of the law of treaties and the law of remedies for a violation of a treaty obligation. The dissenters did not, however, explain why the Court was wrong. As will be explained in the next section, when a court provides a remedy for a violation of a treaty provision, it is not "inserting a clause," but rather is implementing the obligation that was not respected.

\section{INTERNATIONAL LAW ON REMEDY FOR A TREATY VIOLATION}

The Court was wrong to say that VCCR Article 36 leaves the remedy to domestic law. The Court incorrectly cited Article 36, paragraph 2 to reach that conclusion. That paragraph does say, as the Court quotes, that a foreign national's rights are to "be exercised in conformity with the laws and regulations of the receiving State." ${ }^{69}$ That statement is merely a recognition that a foreign national will raise a consular access violation within whatever rules are provided in domestic law to do so. The paragraph also says, as a limitation on the language the Court cited, that even though the matter will be handled under domestic law, "full effect" must be given to the national's rights. ${ }^{70}$ In other words, it is not permissible to invoke rules of domestic law that would defeat the national's rights.

Moreover, regardless of the wording of VCCR Article 36, paragraph 2, the question of remedy for a treaty violation is a matter of international law. The Court's essential error in Sanchez-Llamas was that it ignored that fact.

Treaties typically do not address remedies. ${ }^{71}$ Like domestic contracts, they set out the obligations of the parties. Like domestic contracts, they do not typically spell out the consequences of any breach that might occur. In the domestic law of contract, if a contract calls for a seller to deliver an item, for which the buyer is to pay, the contract need not specify that a failure to pay will require return of the item, or of equivalent value. ${ }^{72}$ That proposition is found in a body of law relating to remedies, and a remedy will be provided even though none is specified in the contract. ${ }^{73}$

${ }^{69}$ VCCR, supra note 8 , art. 36(2).

${ }^{70} \mathrm{Id}$.

${ }^{71}$ LORD ARNOLD MCNAIR, THE LAW OF TREATIES 574 (1961) (stating, in regard to right to reparation for a treaty violation, "[I]t is not necessary that the treaty alleged to be broken ... should refer to reparation").

72 See E. AlLAN FARNSWORTH, CONTRACTS 784 (3d ed. 1999).

${ }^{73} \mathrm{Id}$. 
Treaties, similarly, prescribe obligations. ${ }^{74}$ Only rarely do they address remedy. The basis for a remedy for a treaty violation, and this applies to a violation of VCCR Article 36, is found outside the text of the treaty.

\section{THE LAW OF STATE RESPONSIBILITY}

In international law the rules on remedy for a treaty violation are found in a body of law known as the law of state responsibility. ${ }^{75}$ It is that body of law that deals with general issues of a state's liability for violating its obligations. ${ }^{76}$ Whenever a state violates an international obligation, whether the obligation is found in the customary law of nations, in a multilateral treaty, or in a bilateral treaty, it must make amends. ${ }^{77}$ Without this secondary body of law, treaty obligations would be meaningless, as there would be no remedy. ${ }^{78}$

Hence, when the Supremacy Clause calls on courts to apply treaties as law, that injunction includes not only the treaty's terms, which typically relate only to obligations, but the law of international remedies, which operates as an adjunct to treaty law. ${ }^{79}$

The International Court of Justice (ICJ) has applied the law of state responsibility to find appropriate remedies for treaty breach. For example, in a 1997 case, Czechoslovakia and Hungary had agreed jointly to build waterworks on the Danube River in a bilateral treaty that obligated each to undertake certain aspects of construction and water diversion. ${ }^{80}$ At a certain point, the arrangement went sour. One side, then the other, found reasons not to fulfill its obligations. ${ }^{81}$ The treaty was silent on the consequences of a breach, whether the other party might be entitled to denounce the treaty, or to suspend its own performance. ${ }^{82}$ The ICJ explained that the circumstances that might constitute breach are dealt with in an international body of law on

${ }^{74}$ MCNAIR, supra note 71 , at 4 (defining a treaty as a document that creates a relation between states).

75 IAN BRownlie, Principles of Public INTERNational LaW 435 (5th ed. 1998).

${ }^{76} \mathrm{Id}$.

77 JAMEs Crawford, The INTERnational LAW COMmission's ARTICles on STATE RESPONSIBILITY: INTRODUCTION, TEXT AND COMMENTARIES 83 (2002).

${ }^{78} \mathrm{Id}$. at 16.

${ }^{79}$ Id.

${ }^{80}$ Gabcikovo-Nagymaros Project (Hung. v. Slovk.), 1997 I.C.J. 7 (Sept. 25) [hereinafter Gabcikovo-Nagymaros Project].

${ }^{81}$ Id. at 25.

82 Id. at 62. 
treaties, and that the consequences of breach are found in the law of state responsibility. ${ }^{83}$

Addressing what might occur if a party to a bilateral treaty suspended performance before completion of its obligations, the court said that:

[a]n evaluation of the extent to which the suspension or denunciation of a convention, seen as incompatible with the law of treaties, involves the responsibility of the State which proceeded to it, is to be made under the law of State responsibility. ... It is moreover well established that, when a State has committed an internationally wrongful act, its international responsibility is likely to be involved whatever the nature of the obligation it has failed to respect. ${ }^{84}$

Thus, the issue of the consequences of breach is determined by the law of state responsibility, and that body of law calls for amends of some kind. In the ICJ's view, a state that violates a treaty obligation must take appropriate action to provide a remedy. ${ }^{85}$

The ICJ referred to the Vienna Convention on the Law of Treaties, ${ }^{86}$ a widely ratified treaty that deals with conclusion and performance of treaties, much in the way the domestic law of contracts provides a framework for individual contracts. ${ }^{87}$ The court said that that Convention did not, however, deal with the consequences of a breach, but that a state in breach is nonetheless obliged to assume responsibility:

Thus the Vienna Convention of 1969 on the Law of Treaties confines itself to defining - in a limitative manner - the conditions in which a treaty may lawfully be denounced or suspended; while the effects of a denunciation or suspension seen as not meeting those conditions are, on the contrary, expressly excluded from the scope of the Convention by operation of Article 73 [of that Convention]. It is moreover well established that, when a State has committed an internationally wrongful act,

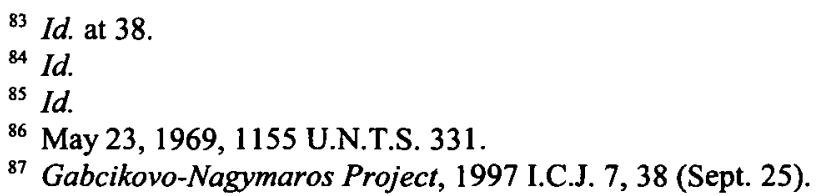


its international responsibility is likely to be involved whatever the nature of the obligation it has failed to respect. ${ }^{88}$

Many authorities rely on an earlier international case for this proposition, the Chorzow Factory case, decided in 1928 by the Permanent Court of International Justice, the predecessor to the International Court of Justice. ${ }^{89}$ In that case the Permanent Court said that where an international obligation is violated, "reparation must, as far as possible, wipe out all the consequences of the illegal act and reestablish the situation which would, in all probability, have existed if that act had not been committed."90

An authoritative statement of the law of state responsibility is found in a contemporary document drafted by the U.N. International Law Commission called Responsibility of States for Internationally Wrongful Acts. ${ }^{91}$ This document was prepared as articles for a possible multilateral treaty. ${ }^{92}$ The International Law Commission is a body created by the U.N. General Assembly in the 1940s to prepare drafts of multilateral treaties on topics in international law. ${ }^{93}$ The document has not been adopted as a treaty, but the U.N. General Assembly has urged states to follow it. ${ }^{94}$ It is widely viewed as setting out what is regarded by states as the customary international law rules on the subject. ${ }^{95}$

The Responsibility of States for Internationally Wrongful Acts document sets out a hierarchy of remedies. ${ }^{96}$ Restoration of the status quo ante is required if possible in the circumstances. ${ }^{97}$ If that is not possible, then financial compensation is required. ${ }^{98}$ If financial compensation is not possible, then "satisfaction" (typically an apology) is required." Article 35 addresses restoration of the status quo ante: "A State responsible for an internationally

${ }^{88} I d$.

${ }^{89}$ See, e.g., BROWNLIE, supra note 75, at 437-38.

${ }^{90}$ Chorzow Factory (Indemnity) (Ger. v. Pol.), 1928 P.C.I.J. (ser. A) No. 17, at 47 (Sept. 13) [hereinafter Chorzow Factory].

${ }^{91}$ U.N. Int'l Law Comm'n, Responsibility of States for Internationally Wrongful Acts, U.N. GAOR, 56th Sess., Supp. No. 10, U.N. Doc. A/56/10 (2001) [hereinafter Draft Articles].

${ }_{92}$ See G.A. Res. 56/83, U.N. Doc. A/RES/56/83 (Jan. 28, 2002).

${ }^{93}$ REBECCA M.M. WALLACE, INTERNATIONAL LAW 31 (2002).

94 G.A. Res. 56/83, supra note 92.

${ }^{95}$ See, e.g., WALLACE, supra note 93, at 175-76.

${ }^{96}$ Draft Articles, supra note 91, arts. 34-37.

97 Id. art. 35.

${ }^{98}$ Id. art. 36.

99 Id. art. 37. 
wrongful act is under an obligation to make restitution, that is, to re-establish the situation which existed before the wrongful act was committed."100 The only exceptions are where restoring the prior situation is "materially impossible" or where such restoration involves "a burden out of all proportion to the benefit deriving from restitution instead of compensation." 101 Article 36 then specifies, "The State responsible for an internationally wrongful act is under an obligation to compensate for the damage caused thereby, insofar as such damage is not made good by restitution."102 Article 37 provides, "The state responsible for an internationally wrongful act is under an obligation to give satisfaction for the damage caused by that act insofar as it cannot be made good by restitution or compensation." 103

In situations in which Article 36 of the VCCR is violated, it is often possible to physically restore the status quo ante, at least in some measure, that is, if the foreign national was not sentenced to death or, if sentenced to death has not yet been executed. ${ }^{104}$ If the foreign national has not been executed, criminal proceedings following the failure to inform at the time of arrest, and the consequences of those proceedings, can be reversed. ${ }^{105}$ That result would not fully restore the status quo ante because the person may have been held in jail for some years. ${ }^{106}$ Financial compensation may be required for that aspect of the person's treatment. ${ }^{107}$

The Restatement: Foreign Relations Law of the United States, a document detailing rules of customary international law, characterizes the law of state responsibility in terms similar to those used by the ILC. ${ }^{108}$ The Restatement posits:

A state is responsible for any violation of its obligations under international law resulting from action or inaction by

(a) the government of the state,

100 Id. art. 35.

${ }^{101} I$ d. art. 35(a), (b).

102 Id. art. 36.

${ }^{103}$ Id. art. 37.

104 See LaGrand Case (Ger. v. U.S.), 2001 I.C.J. 466, 513-14 (June 27) [hereinafter LaGrand Case].

${ }^{105}$ Id.

106 Id. at 475.

${ }^{107}$ Draft Articles, supra note 91, art. 36.

${ }^{108}$ RESTATEMENT (THIRD) OF THE FOREIGN RELATIONS LAW OF THE UNITED STATES (1987). 
(b) the government or authorities of any political subdivision of the state, or

(c) any organ, agency, official, employee, or other agent of a government or of any political subdivision, acting within the scope of authority or under color of such authority. ${ }^{109}$

The Restatement further addresses state responsibility in the context of violation of the rights of a foreign national:

A state is responsible under international law for injury to a national of another state caused by an official act or omission that violates

(a) a human right that ... a state is obligated to respect for all persons subject to its authority;

(b) a personal right that, under international law, a state is obligated to respect for individuals of foreign nationality; . . ${ }^{110}$

Finally, the Restatement indicates, in terms similar to those of the ILC, that a remedy is required whenever a state violates an obligation: "Under international law, a state that has violated a legal obligation to another state is required to terminate the violation and, ordinarily, to make reparation, including in appropriate circumstances restitution or compensation for loss or injury." 11 The Restatement's Reporter cited the Chorzow Factory case ${ }^{112}$ to say that restoring the prior existing situation is required. ${ }^{113}$

Apart from the question of which remedy is required, a remedy of some sort is required for a treaty violation, even if the treaty is silent on the issue of remedy. ${ }^{114}$ The Court's error in Sanchez-Llamas was that it disregarded the fact that the consequences of a treaty violation are covered by the law of state responsibility, and that when a treaty is violated that body of law calls for a remedy.

109 Id. $\$ 207$.

110 Id. $\$ 711$.

111 Id. $\$ 901$.

112 Chorzow Factory, 1928 P.C.I.J. (ser. A) No. 17, at 47 (Sept. 13).

113 RESTATEMENT, supra note $108, \S 901 \mathrm{n} .3$.

114 See supra notes 75-113 and accompanying text. 


\section{STATE RESPONSIBILITY FOR VIOLATION OF CONSULAR ACCESS}

The issue of remedy for a violation of the right of consular access has arisen before two international courts. ${ }^{115}$ Each court considered the issue and gave a decision at odds with the Sanchez-Llamas statement that any remedy to be given must be found within the provisions of the violated treaty. ${ }^{116}$ The two courts, the Inter-American Court of Human Rights and the International Court of Justice, each drew the conclusion that failure to inform a foreign national of the right of consular access must be remedied. ${ }^{117}$ Neither took the view that it had to find a remedy provision in the VCCR itself.

The Inter-American Court of Human Rights was asked to issue an advisory opinion on consular access in the specific context of imposition of capital punishment on a foreign national. In other words, what consequences follow if a foreign national is not notified about consular access upon arrest but is then convicted and sentenced to death ${ }^{118}$ The Court decided that the imposition of a death sentence without compliance with the obligation to inform detainees of the right of consular access constitutes an arbitrary deprivation of life, hence a violation of the foreign national's human rights. ${ }^{119}$ In a concluding paragraph, the Court addressed the question of remedy:

For the foregoing reasons, the Court concludes that nonobservance of a detained foreign national's right to information, recognized in Article 36(1)(b) of the Vienna Convention on Consular Relations, is prejudicial to the guarantees of the due process of law; in such circumstances, imposition of the death penalty is a violation of the right not to be "arbitrarily" deprived of one's life, in the terms of the relevant provisions of the human rights treaties (eg the American Convention on Human Rights, Article 4; the International Covenant on Civil and Political Rights, Article 6) with the juridical consequences inherent in a violation of this nature, i.e.,

115 The Right to Information on Consular Assistance in the Framework of the Guarantees of Due Process of Law, Advisory Opinion OC-16/99, Inter-Am. Ct. H.R. (ser. A) (Oct. 1, 1999) [hereinafter Inter-Am. Ct. H.R., Advisory Opinion]; LaGrand Case, 2001 I.C.J. 466 (June 27).

${ }^{116}$ Inter-Am. Ct. H.R., Advisory Opinion, supra note 115; LaGrand Case, 2001 I.C.J. at 514.

117 Inter-Am. Ct. H.R., Advisory Opinion, supra note 115, ๆ 137; LaGrand Case, 2001 I.C.J. at 514 .

${ }^{118}$ Inter-Am. Ct. H.R., Advisory Opinion, supra note 115, $\uparrow 1$.

119 Id. \ 137. 
those pertaining to the international responsibility of the State and the duty to make reparations. ${ }^{120}$

The Inter-American Court thus referred to the law of state responsibility as the source for a requirement of remedy. ${ }^{121}$ The "juridical consequence" of a violation was an obligation to make reparations, as required by the law of state responsibility. ${ }^{122}$

The International Court of Justice similarly found a remedy to be required in the event of a consular access violation. ${ }^{123}$ Germany had sued the United States, seeking an order against the pending execution of a German national who had been convicted of murder and sentenced to death in Arizona. ${ }^{124}$ The German national had not been informed upon arrest of the right of consular access. ${ }^{125}$ The United States admitted the violation of the obligation to notify the national but said that the violation did not preclude executing him. ${ }^{126}$ The United States argued that it could remedy the violation by apologizing to Germany. ${ }^{127}$ The court rejected that position. ${ }^{128}$

The Court addressed the issue of remedy in the broader context of German nationals who might be arrested in the United States. ${ }^{129}$ The Court said:

[I] $\mathrm{f}$ the United States ... should fail in its obligation of consular notification to the detriment of German nationals, an apology would not suffice in cases where the individuals concerned have been subjected to prolonged detention or convicted and sentenced to severe penalties. In the case of such a conviction and sentence, it would be incumbent upon the United States to allow the review and reconsideration of the conviction and sentence by taking account of the violation of the rights set forth in the Convention. ${ }^{130}$

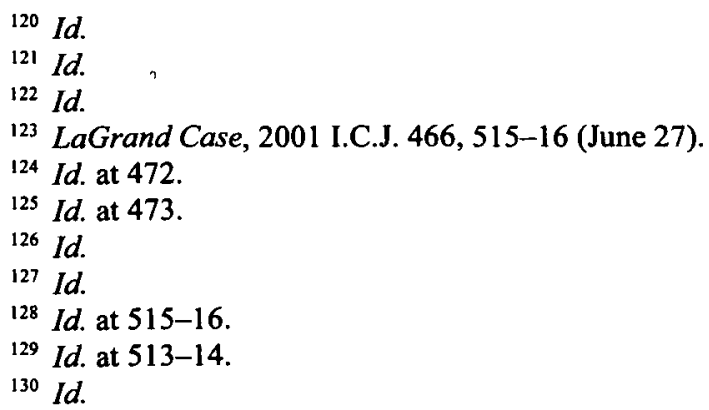


The Court thus was employing the law of state responsibility in calling for restoration of the status quo ante. ${ }^{131}$

\section{VIEWS OF STATES PARTY TO THE VCCR}

Many states that are party to the VCCR have said, consistent with these decisions, that a remedy is required in response to a violation of VCCR Article 36. ${ }^{132}$ In an earlier VCCR case in the United States Supreme Court, the European Union and the Council of Europe, together representing forty-six European nations, all of whom have ratified the VCCR, filed an amicus curiae brief asking the Court to provide a remedy in accordance with the ICJ opinion in LaGrand. ${ }^{133}$ In regard to treaties, the practice of ratifying states is viewed as relevant on issues of interpretation. ${ }^{134}$ The fact that so many states party to the VCCR view a remedy as being required is strong evidence that the treaty does in fact require one. ${ }^{135}$

One of the few cases to reach the highest court of a state party to the VCCR was decided only a few months after Sanchez-Llamas by the German Constitutional Court. ${ }^{136}$ The German court ruled that when consular access is violated and a foreign national is convicted, the conviction must be reviewed. ${ }^{137}$ As to the suppression of a statement made by a foreign national who was not informed about consular access, the German court said that Article 36 is a first line of defense for foreign nationals in regard to their normally weaker legal and psychological position in comparison to natives. ${ }^{138}$

In Australia, no case has reached the highest court. However, two cases have reached the highest courts of Australia's federative states. ${ }^{139}$ In one case,

131 Id. at 514.

${ }^{132}$ Brief for the European Union and Members of the International Community as Amici Curiae Supporting Petitioner at 8-9, Medellin v. Dretke, 544 U.S. 660 (2005) (No. 04-5928), 2005 WL 152924.

${ }^{133} \mathrm{Id}$.

134 Vienna Convention on the Law of Treaties, supra note 86, art. 31(3)(b).

135 WALLACE, supra note 93, at 16-19.

${ }^{136}$ Bundesverfassungsgericht [BVerfG] [Federal Constitutional Court] Sept. 19, 2006, 2 Entscheidungen des Bundesverfassungsgerichts [BVerfGE] 21 15/01 (F.R.G.), available at http:// www.bverfg.de/entscheidungen/rk20060919_2bvr211501.html.

137 Id. $\uparrow 68$.

${ }^{138}$ Id. 974.

139 Tan Seng Kiah v. Queen (2001) 160 F.L.R. 26 (Austl.); Queen v. Kok Cheng Tan (2001) W.A.R. 275 (Austl.). 
a Singapore national was convicted of importing heroin into Australia. ${ }^{140}$ After being arrested, he asked for access to the Consular Office of Singapore. ${ }^{141}$ The authorities did nothing to facilitate access. ${ }^{142}$ Instead, they interrogated him, eliciting a statement that in the prosecution's view contained lies which suggested guilt. ${ }^{143}$ The statement was not a confession, however. ${ }^{144}$

The Court explained that the Australian statutory provision implementing Article $36^{145}$ was silent as to a remedy in the event that the authorities failed to comply with consular access. ${ }^{146}$ The Court said, however:

Contacting the consular office by a detained foreign national provides an opportunity to report his or her circumstances, seek advice and assistance, provides a means of informing relatives and friends of his or her situation and all this in his or her native language. One need only contemplate the predicament of an Australian national held in custody in a foreign non-English speaking country without access to an Australian consular office to appreciate the importance of the right contained in $\mathrm{s} 23 \mathrm{P}$ of the Crimes Act. ${ }^{147}$

The Court said that, although the authorities did not apply pressure to gain a statement, " $[t]$ he fact remains that he may not have agreed to be interviewed or the interview may have followed a different path had the applicant been dealt with in compliance with the provisions of the Crimes Act."148 The Court concluded that "the proper exercise of the discretion" required exclusion of the statement. ${ }^{149}$ The Court viewed suppression as required even though neither

${ }^{140}$ Tan Seng Kiah (2001) 160 F.L.R. 26. The Northern Territory is a federal territory rather than a state. Its highest court occupies a place comparable to that of the highest court of a state.

${ }^{141}$ Id. $\uparrow 47$. He also asked to see an attorney.

${ }^{142} I d$. 148 . The authorities similarly did not facilitate access to an attomey.

${ }^{143} I d$. $\ 69$.

144 Id.

145 Australia, which has no constitutional provision comparable to the Supremacy Clause of the U.S. Constitution, incorporates treaty provisions into domestic law by statute. See Crimes Act, 1914, § 23P (Austl.), discussed infra note 157.

${ }^{146}$ Tan Seng Kiah (2001) 160 F.L.R. 26, ๆ 55.

${ }^{147}$ Id. ๆ 49.

${ }_{148}^{14}$ Id. $\lceil 66$.

149 Id. 772 . The decision to exclude was based both on the failure to afford access both to a consul and to an attorney. Id. 
Article 36 nor the Australian implementing law mentions suppression or other remedies. $^{150}$

In the other Australian case, the issue was suppression of narcotics seized from a travel bag of a Japanese national who was being detained in a fashion that implicated Article $36 .^{151}$ The authorities had not informed the man of his right to contact a consul. ${ }^{152}$ The Court suppressed the narcotics on the sole ground that the detention was unlawful because of the authorities' failure to inform the national about his right to consular access. ${ }^{153}$

In Sanchez-Llamas, the Court acknowledged the Australian cases, ${ }^{154}$ and the dissenters relied on the Tan Seng Kiah case. ${ }^{155}$ The Court dismissed the two cases as having been decided on the basis of an Australian statute "that provides rights beyond those required by Article 36 itself." 156 The Court's dismissal of the two cases is questionable, however. The Court did not explain why it thought the Australian statute goes beyond what is required by Article 36. One may imagine that it is because the Australian statute specifically requires that the foreign national be informed about consular access prior to any interrogation. ${ }^{157}$ Article 36 does not in terms do so. But the

${ }^{150} \mathrm{Id}$.

151 Queen v. Kok Cheng Tan (2001) W.A.R. 275 (Austl.).

152 Id. Breyer, in dissent, characterized this case as an "Australian case considering but declining to suppress evidence based on [a] violation of [the] same statute." Sanchez-Llamas v. Oregon, 126 S. Ct. 2669, 2707 (2006) (Breyer, J., dissenting). However, the evidence in question was the narcotics found in the travel bag, which the court did in fact suppress.

${ }^{153}$ Kok Cheng Tan (2001) W.A.R. 275, I 59.

$154126 \mathrm{~S}$. Ct. at 2678 n.3.

155 Id. at 2707.

${ }^{156}$ Id. at 2678 n.3.

${ }^{157}$ Crimes Act, 1914, $\S 23 \mathrm{P}$ (Austl.). This provision as amended in 1991, read as follows at the time of the two cases:

23P. (1) Subject to section 23L [which allows for departure in case of specified exigent circumstances] if a person under arrest for a Commonwealth offence is not an Australian citizen, the investigating official holding the person under arrest must, before starting to question the person:

(a) inform the person that he or she may communicate with or attempt to communicate with, the consular office of the country of which the person is a citizen; and

(b) defer the questioning for a reasonable time to allow the person to make, or attempt to make, the communication.

(2) Subject to section $23 \mathrm{~L}$, if the person wishes to communicate with a consular office, the investigating official holding the person under arrest must, as soon as practicable, give the person reasonable facilities to do so.

In late 2001, the above language was repealed and replaced as follows: 
Australian provision was enacted to bring Australian law into conformity with Article 36, and there is no indication that Australia meant to go beyond Article 36. ${ }^{158}$ Rather, it appears that it was the Australian understanding that the obligation to inform a foreign national required that this be done prior to interrogating him. ${ }^{159}$

In these two cases, the Australian courts were thus presented with the issue of excluding, in the one instance a statement and in the other material evidence, for failure to comply with the VCCR's provisions regarding consular

23P. (1) Subject to section 23L, if a person who is under arrest or a protected suspect is not an Australian citizen, an investigating official must, as soon as practicable: of:

(a) inform the person that if he or she requests that the consular office

(i) the country of which he or she is a citizen; or

(ii) the country to which he or she claims a special connection; be notified that he or she is under arrest or a protected suspect (as the case requires), that consular office will be notified accordingly; and

(b) if the person so requests-notify that consular office accordingly; and

(c) inform the person that he or she may communicate with, or attempt to communicate with, that consular office; and

(d) give the person reasonable facilities to do so; and

(e) forward any written communication from the person to that consular office; and

(f) allow the person a reasonable time to, or to attempt to, communicate with that consular office.

(2) Without limiting subsection (1), an investigating official must

not start to question the person unless paragraphs (1)(c), (d) and

(f) have been complied with.

158 New South Wales L. Ref. Comm'n, Rep. No. 66, Criminal Procedure: Police POWERS OF DETENTION AND INVESTIGATION AFTER ARREST ๆ 5.43 (1990), available at http:// www.lawlink.nsw.gov.au/lrc.nsf/pages/R66TOC. Citing the federal Gibbs Committee's Review of Commonwealth Criminal Law, which made recommendations that led to the adoption of $\S 23 \mathrm{P}$, the New South Wales Law Reform Commission stated,

The Review Committee of Commonwealth Criminal Law has recommended adoption of this provision [on the right of a foreign national to consular access] at the federal level. This right derives from Article 36 of the Vienna Convention on Consular Relations, brought into force in Australia by the Consular Privileges and Immunities Act 1972.

Id. ${ }^{159}$ Id. 
access. ${ }^{160}$ Even absent any treaty or statutory provision requiring these remedies, the two Australian courts regarded the exclusion as required. ${ }^{161}$

The U.S. Supreme Court in Sanchez-Llamas Court mentions, as well, that several amici cited United Kingdom cases. ${ }^{162}$ In the UK, no cases have been decided by higher courts. The reference was evidently to two decisions at the trial level in which the judge excluded incriminating statements of foreign nationals convicted, in both instances, of drug smuggling because they had not been informed of their right to consular access. ${ }^{163}$

The dissenters in Sanchez-Llamas relied, as well, on a trial-level Canadian case, $R v$. Partak. $^{164}$ In that case, a U.S. national sought to suppress an incriminating statement made to Canadian authorities while he was in custody and without having been informed of the right to consular access. ${ }^{165}$ The court denied his motion. ${ }^{166}$ The Sanchez-Llamas dissenters quote the judge as having said that his reason for denying suppression was that Partak "completely failed to demonstrate any prejudice arising from the failure of the police to notify him of his consular rights." 167 They therefore read the case as taking the view that suppression might be appropriate if introduction prejudiced the foreign national. ${ }^{168}$

The Court disputed the dissenters' reading of Partak as follows: "The Canadian case on which the dissent relies . . . denied suppression, and concerned only the court's general discretionary authority to exclude a confession 'whose admission would adversely affect the fairness of an accused's trial." "169 The Court thus sought to read Partak as giving no indication that suppression might ever be required for a consular access violation. ${ }^{170}$ The dissenters have the better reading of the case, however. The judge's reason for denying suppression is that, as he understood the facts, Partak was extremely anxious to confess to the murder of which he was

160 Tan Seng Kiah v. Queen (2001) 160 F.L.R. 26 (Aust.); Queen v. Kok Cheng Tan (2001) W.A.R. 275 (Austl.).

161 Sanchez-Llamas, 126 S. Ct. at 2678 n.3.

162 Id.

${ }_{163}$ R v. Bassil \& Mouffareg, Legal Action, Dec. 1990, at 23 (Acton Crown Ct. 1990); R

v. Van Axel \& Wezer, Legal ACTION, Sept. 1991, at 12 (Snaresbrook Crown Ct. 1991).

${ }^{164}$ [2001] 160 C.C.C.(3d) 553 (Ont.); Sanchez-Llamas, 126 S. Ct. at 2707.

165 Partak, 160 C.C.C.(3d) at 556.

${ }^{166} \mathrm{Id}$. at 570.

167 Sanchez-Llamas, 126 S. Ct. at 2707.

${ }_{168}$ Id.

169 Id. at 2678 n.3.

${ }^{170} \mathrm{Id}$. 
suspected; hence, it would have been unlikely that notifying him about consular access would have changed how he conducted himself with the authorities. ${ }^{171}$

The Court read the foreign practice as showing no support for the approach of suppression, primarily on the paucity of court cases in which a statement was suppressed for a consular access violation. ${ }^{172}$ As the dissenters point out, however, in civil law systems, pre-trial motions are not typically used, and decisions about using, or not using, a statement would be made by an examining magistrate or a trial judge, without a motion having been made. ${ }^{173}$

The Court bolsters its refusal to suppress by claiming that suppression is a remedy used nowhere in the world except in the United States:

It would be startling if the Convention were read to require suppression. The exclusionary rule as we know it is an entirely American legal creation. More than 40 years after the drafting of the Convention, the automatic exclusionary rule applied in our courts is still "universally rejected" by other countries. ${ }^{174}$

Hence, the Court implies that suppression is not used outside the United States, and thus could not possibly be contemplated as a remedy for a VCCR Article 36 violation. ${ }^{175}$

As indicated, however, a number of foreign courts have used suppression for a VCCR Article 36 violation. ${ }^{176}$ But they use it more generally to remedy other procedural violations. ${ }^{177}$ Contrary to the implication of the Court's quotation of Professor Bradley, that author does not say that statements are not suppressed when unlawfully obtained. Bradley in fact says, after reviewing foreign practice, that evidence often is excluded for having been unlawfully obtained. ${ }^{178}$ What Bradley says has been "universally rejected" is Mapp v.

171 Partak, 160 C.C.C.(3d) at 570.

172 Sanchez-Llamas, $126 \mathrm{~S}$. Ct. at 2678 n.3.

173 Id. at 2707-08.

${ }^{174}$ Id. at 2678 (citations omitted) (quoting Craig M. Bradley, Mapp Goes Abroad, 52 CASE W. RES. L. REV. 375 (2001)).

${ }_{175}$ Id.

${ }_{176}$ See supra notes 139-53, 163 and accompanying text.

${ }_{177}$ Bradley, supra note 174.

${ }^{178}$ Id. at 399. 
Ohio' $\mathrm{s}^{179}$ requirement that unlawfully obtained evidence must in all instances be excluded. ${ }^{180}$

\section{VIEW OF THE DEPARTMENT OF STATE}

Of course the view of the United States as a party to the VCCR is also relevant. The Department of State in recent years has argued that no judicial remedy is required when consular access is violated. ${ }^{181}$ In a 1998 case filed against it in the ICJ by Paraguay, the Department espoused a view quite close to that of the Court in Sanchez-Llamas. ${ }^{182}$ Virginia was about to execute a Paraguayan convicted of murder, but who had not been informed at the time of arrest of his right to contact a Paraguayan consul. ${ }^{183}$ In response to Paraguay's request for an injunctive order to stop the execution, the Department of State argued to the International Court of Justice:

Paraguay's application maintains that the necessary legal consequence for any such breach is that the ensuing conviction and sentence must be put aside. There is absolutely no support for this claim in the language of the Convention. The Court should not read into a clear and nearly universal multilateral instrument such a substantial and potentially disruptive additional obligation that has no support in the language agreed by the parties. ${ }^{184}$

Again focusing on the language of the VCCR, the Department told the ICJ, "Absolutely nothing in the language of Article 36, paragraph 1 of the Vienna Convention on Consular Relations (or any other Article of the Convention) offers support for Paraguay's claim that failure of consumer notification requires invalidation of any subsequent conviction and sentence of an alien."185

179368 U.S. 871 (1961) (establishing the exclusionary rule).

180 Bradley, supra note 174 , at 399 . Bradley acknowledges, in his article, exceptions in our own case law that make exclusion less than automatic.

${ }^{181}$ See Oral Arguments on the Request for the Indication of Provisional Measures, Vienna Convention on Consular Relations (Para. v. U.S.), 2000 I.C.J. Pleadings 45 (Apr. 7) [hereinafter Oral Arguments].

${ }_{182}$ Id.

183 Breard v. Greene, 523 U.S. 371, 372 (1998).

184 Oral Arguments, supra note 181 , at 45.

185 Id. at 44. 
That position was at odds with the position the Department argued when it found itself on the other side of a VCCR case, namely when U.S. consuls had been taken hostage in Iran. ${ }^{186}$ When that occurred, the United States sued Iran over the hostage-taking and used VCCR Article 36 as a basis for its demand that Iran release those it held. ${ }^{187}$ Just as suppression of an incriminating statement is not mentioned in the VCCR, so too release of consuls held hostage is not mentioned. Nonetheless, the Department told the ICJ that Article 36 required release. ${ }^{188}$ The Department found no obstacle in the fact that such a remedy is not mentioned in Article 36. It argued that once a situation is determined to be illegal, the state in breach is under an obligation to bring that situation to an end. ${ }^{189}$ The ICJ accepted the Department's argument and ordered Iran to release the hostages. ${ }^{190}$

\section{CONCLUSION}

The Court's broad proposition that in the event of a treaty violation, only a remedy specified in that treaty need be given would bring a serious erosion of the Constitution's Supremacy Clause provision on treaties. In the VCCR context, it also puts the United States in violation of its international obligation, because it means that U.S. courts will not be giving remedies required when U.S. authorities fail to comply. The United States should be providing a remedy when it fails to comply with the VCCR Article 36 obligation. The Court compounded its error as to remedy by misreading foreign court decisions that called for suppression as a remedy for an Article 36 violation.

The Court, as indicated, did not explain the reasoning that led it to the unfortunate position that only remedies specified in a treaty must be used. The Court was apparently unaware of how remedies work for treaty violations.

${ }^{186}$ B. Drummond Aryes, Jr., Ex-hostage, Resting in Maine, Describes Ordeal, N.Y. TimEs, July 27, 1980, at A1 (stating how one of the detained consuls described situation of U.S. personnel taken hostage and held at U.S. embassy in Tehran).

${ }^{187}$ United States Diplomatic and Consular Staff in Tehran (U.S. v. Iran), 1980 I.C.J. 3, 6 (May 24) [hereinafter ICJ Decision].

188 Id.

189 Memorial of the United States (U.S. v. Iran), Case Concerning United States Diplomatic and Consular Staff in Tehran, 1982 I.C.J. Pleadings 188 (Jan. 12).

190 The Department has not offered an explanation of the difference between the view it stated in 1998 in the Paraguay case, and the view it stated in 1980 in the Iran case. ICJ Decision, 1980 I.C.J. at 44. 
Once that process is understood, as it hopefully will be in future cases, the Court should be able to deal properly with treaty violations. 